\title{
FOLLICULAR DYNAMICS, OVULATION AND REPRODUCTIVE HORMONES FOLLOWING GNRH PRE-TREATMENT IN POST PARTUM SUCKLED DAIRY BUFFALO- COWS
}

\author{
BR. ABDEL-HALIM* and NERMEEN A. HELMY** \\ *Department of Theriogenology, Faculty of Veterinary Medicine, Beni-Suef University, Beni-Suef, Egypt, Tel/ \\ Fax:0020822327982. \\ ${ }^{* *}$ Department of Physiology, Faculty of Veterinary Medicine, Beni- Suef University, Beni-Suef, Egypt. \\ Email: drbakarwa@yahoo.com
}

\section{ABSTRACT}

Received at: 16/3/2014

Accepted: $26 / 4 / 2014$
The objective of this study was to investigate the role of administration of gonadotropin-releasing hormone $(\mathrm{GnRH})$ at day 12-14 postpartum on ovarian dynamics and conception rates in buffalo- cows. The study was conducted on twenty four, apparently healthy, lactating buffalo-cows in their second to fifth parity. The animals were divided into two groups; group $I(n=10)$ considered as control group that did not receive any treatment and group II $(n=14)$ that received $100 \mu \mathrm{g}$ GnRH (Receptal ${ }^{\circledR}$ ) for each animal during the period from 12-14 days post partum. Ovarian structures were monitored daily, from day 6 postpartum until detection of the third postpartum ovulation, using a real- time ultrasound. Blood samples were collected via the coccygeal vein from day 6 post treatment and every 3 days until detecting the third postpartum ovulation to estimate serum progesterone, serum luteinizing hormone, and Follicle stimulating hormone profiles. All animals ovulated before day 45 postpartum in GnRH treated group $(14 / 14,100 \%)$; whereas, none of the cows in control group ovulated within this period of time. Interval from calving to the first ovulation and from calving to the second and the third ovulations in GnRH treated group was significantly shorter $(23.6 \pm 1.4,45.2 \pm 2.3$ and $67.8 \pm 1.9$ days respectively) than in control group $(65.1 \pm 5.8,87.6 \pm 6.4$ and $119.2 \pm 6.3$ days respectively). The mean serum progesterone concentrations were significantly higher in treated group in the first and the second cycle $(3.6 \pm 0.2$ and $4.1 \pm 0.1 \mathrm{ng} / \mathrm{ml})$ than in the control group $(1.8$ \pm 0.3 and $3.1 \pm 0.6 \mathrm{ng} / \mathrm{ml}$ respectively). The pattern of $\mathrm{LH}$ release was similar in both treated and control groups, while the peak LH was significantly higher in treated group $(21.4 \pm 3.8 \mathrm{ng} / \mathrm{ml})$ than the control group $(12.8 \pm 1.9 \mathrm{ng} / \mathrm{ml})$. The actual intervals from calving to first behavioral estrus and the actual interval from calving to conception (days open) were significantly shorter in treated group (42.6 \pm 1.8 days, $86.9 \pm 1.6$ days respectively) than the control group $(65.2 \pm 3.4,100.4$ \pm 2.6 days respectively). The conception rate was higher in treated group (77.4 \pm $1.9)$ compared to control group $(55.8 \pm 2.6)$. From the current study we concluded that, GnRH treatment on day 12-14 postpartum stimulate early ovulation in buffalo- cows, thus stimulate the postpartum behavioral estrus, shorten number of days open, decrease number of services per conception and improve the conception rate.

Keywords: GnRH; ovarian dynamics; hormonal profile; conception rate; buffalo-cows.

\section{INTRODUCTION}

Buffalo-cows (Bubalus bubalis) are of high economic importance in various developing countries but reproductive performance is poor. The incidence of anoestrus in buffaloes ranges from 20 to $80 \%$ depending on seasonal factors (Nanda et al., 2003).
Most buffaloes cease ovarian cyclicity during hot summers probably due to the combined effects of nutrition, environment and management (Das and Khan, 2010). The reproductive process in buffalocows is very slow characterized by delayed onset of puberty, long postpartum anoestrus and an extended inter-calving interval (Nanda et al., 2003). Suckled buffaloes have significantly delayed onset of 
postpartum ovarian activity (Arya and Madan, 2001). The poor reproductive performance, especially in postpartum buffaloes, could be attributed to suckling, which is commonly practiced to induce milk letdown in smallholder dairy-farming systems (Sastry et al., 1994). Suckling, an exteroceptive stimulus, suppresses episodic pituitary gonadotropin leading to anoestrus and / or anovulation in several female mammals, including sheep, rat, monkey and humans (McNeilly, 1988). However, the effects of suckling on pituitary functions and other reproductive parameters are still not fully understood in buffaloes. Problems related to estrus detection constitute a major constraint to increase reproductive rates in the water buffalo (Shah et al., 1990; Barkawi et al., 2003 and Abdel-Ghani, 2005). This consideration indicates a need for estrus synchronization using fixed time insemination for implantation of breeding programs in buffaloes. To date, the most common synchronization schemes in buffaloes are limited either to premature regression of the corpus luteum (CL) by injection of PGF2 $\alpha$ or its synthetics analogues (Singh and Dabas, 1998; Abol-Roos and Gaffar, 2000 and Brito et al., 2002) or by prolonging the life span of the CL by progesterone (Subramaniam and Devarajan, 1991; Luthra et al., 1994; Pursley et al., 1995 and Barile et al., 2001). The difficulty with these approach programs in noncyclic buffaloes has not been fully studied. The Ovsynch, developed in cattle (Pursley et al., 1995), has been recently practiced in nulliparous and multiparous (Presicce et al., 2005), lactating and non lactating and cyclic and non cyclic buffaloes (Paul and Prakash, 2005). The conception rate (CR) of this program is still, however, extremely low in the non cyclic buffaloes (DeRensis et al., 2005). The reduced CR may be attributed to a true deep acyclic condition that is characterized by an absent or strongly reduced follicle turnover. Therefore, attainment of an adequate size of a dominant follicle required for responsiveness to GnRH may not be reached. Another explanation is that animals may be unresponsive to prostaglandin administration due to insufficient or absent luteal tissue. The administration of GnRH and GnRH analogues induces an acute release of gonadotropin in cattle (Martinez et al., 2003) and buffaloes (Rastegarnia et al., 2004). The effect of exogenous GnRH or equine chorionic gonadotropin (eCG) is essential to enhance the reproductive performance of buffaloes. The incidence of anoestrus in buffaloes ranges from 20 to $80 \%$ depending on seasonal factors. In cattle High concentrations of plasma $\mathrm{LH}$ and $\mathrm{FSH}$ following treatment with GnRH are typically greater than concentrations associated with pre-ovulatory gonadotropin surge but the release of gonadotropin, however, is of shorter duration (Martinez et al., 2003). The injection of GnRH induces ovulation for follicles that are at the appropriate maturational stage and posses the revealant $\mathrm{LH}$ receptors (Xu et al.,
1995). In buffaloes, treatment with GnRH has been shown to induce ovulation that is accompanied by the appearance of luteal tissue on the ovary within $14 \mathrm{~h}$ and increased circulating concentrations of progesterone within $96 \mathrm{~h}$ (Campanile et al., 2008). The aim of the present study was to characterize the pituitary and ovarian response to treatment with a GnRH on day 12-14 postpartum in buffaloes. Attention was directed also to investigate the potency of $\mathrm{GnRH}$ to induce ovulation, formation of an accessory CL and increase circulating concentration of progesterone. It was also aimed to study the effect of GnRH on ovarian dynamics, hormonal profile and conception rate in cycling buffalo-cows.

\section{MATERIALS and METHODS}

\section{Animals, management and experimental design}

The current study was conducted on twenty four, apparently healthy, lactating buffalo-cows (Bubalus bubalis) in their second to fifth parity during the period from April to November, 2013 in Beni-Suef Province, Egypt. The animals were fed ad libtum with seasonal green fodder and wheat straw. In addition, $1 \mathrm{~kg}$ of concentrates was given for each kilogram of milk produced. The buffaloes had calved 12-14 days before the start of the treatment. Calves from these buffaloes were allowed to suckle for 5-10 min. before and after each milking, twice daily. The buffaloes were hand milked twice daily, at early morning and at evening. The animals had undergone a general veterinary assessment of their reproductive tract and ovaries by rectal palpation and none had any apparent abnormality. The animals were divided into two groups, group I $(\mathrm{n}=10)$ considered as control group without any treatment and group II $(n=14)$ received $100 \mu \mathrm{g} \mathrm{GnRH}$, $\left(\right.$ Receptal $\left.^{\circledR}\right)$ from Schering- Plough, MSD Animal Health, is a subsidiary of Merck \& Co., Inc., Whitehouse Station, NJ, USA for each animal during the period from 1214 days postpartum because the pituitary sensitivity, as reflected by $\mathrm{LH}$ response to synthetic $\mathrm{GnRH}$, is suppressed in the immediate postpartum period and increases gradually by time (DeRensis et al., 1993) till recovery on day 14 after calving (Alam and Dobson, 1987). Estrus detection was done by close observation from day 6 postpartum, buffaloes observed carefully in the early hours of the morning, the late hours of the evening and at 4-5h intervals during the day (Wattiaux, 1995). All animals were inseminated artificially by good quality semen and at the optimum time during estrus.

\section{Ovarian and uterine examination by Ultrasonography}

Ovarian structures (follicle and CL) and uterine changes were monitored daily, from day 6 postpartum until detection of the third postpartum 
ovulation, using a real- time ultrasound scanner, equipped with 6-8 MHz rectal transducer probe (Piemedical, Netherland) The day of ovulation was confirmed by the disappearance of the largest follicle followed by the formation of CL and increase in plasma progesterone concentrations. The diameters of ovarian follicles and CLs were recorded. Dominant follicle was recorded as ovulatory or non ovulatory follicle.

\section{Reproductive parameters}

Days from parturition to the first, second and third postpartum ovulations were calculated. Functional lifespan of $\mathrm{CL}$ was estimated from the day of ovulation until the day in which progesterone concentration declined for $1-2 \mathrm{ng} / \mathrm{ml}$ from the previous day, followed by the progressive decline of progesterone (regression of CL). Average diameter of CL, throughout estrous cycle, was estimated from the initial detection of CL by ultrasound to the time that CL diameter decreased for $2 \mathrm{~mm}$ from the previous day and continued to decline progressively. Average progesterone concentrations, throughout reproductive cycle, were calculated from the initial rise until return to the basal progesterone concentrations $(0.2 \mathrm{ng} / \mathrm{ml})$. In addition, the time from parturition till conception (days open), number of services per conception (NSC) and conception rate (CR) were recorded.

\section{Estimation of progesterone concentrations $\left(\mathbf{P}_{4}\right)$} Blood samples were collected via the coccygeal vein from day 6 post treatment and every 3 days until detecting the third postpartum ovulation. Collection was completed in clean dry and sterilized plastic test tubes and left overnight then centrifuged at $1500 \times \mathrm{g}$ value for 10 minutes to separate the serum. The harvested serum was stored at $-20^{\circ} \mathrm{C}$ until assayed for $\mathrm{P}_{4}$ concentration. $\mathrm{P}_{4}$ concentration in serum was determined using ELISA technique, using the specific kits (EIA-1561, DRG diagnostics Instrument $\mathrm{GmbH}$, Germany). The sensitivity of the assay was $0.045 \mathrm{ng} / \mathrm{ml}$, the intra and inter-assay coefficient of variation were $6.99 \%$ and $9.96 \%$ (Less than $10 \%$ ).

\section{Estimation of FSH \& LH Profiles}

An LH pulse was defined as a rise in serum concentration of the hormone, two consecutive samples greater than the mean of the two previous samples, when the value of at least one of the peak samples exceed the mean by more the twice the intraassay coefficient of variation (McNeilly and Baird, 1983). Blood samples were collected via the coccygeal vein at $0 \mathrm{~h}, 30 \mathrm{~min}, 1 \mathrm{~h}, 2 \mathrm{~h}, 3 \mathrm{~h}$, and $4 \mathrm{~h}$ following GnRH treatment in a clean dry and sterilized plastic test tubes and left overnight then centrifuged at $1500 \times \mathrm{g}$ value for 10 minutes to obtain the serum and stored at $-20{ }^{\circ} \mathrm{c}$ until assayed for FSH \& $\mathrm{LH}$ concentration. Interval from $\mathrm{GnRH}$ injection to start of hormone rise (hours), Interval from GnRH injection to peak value (hours) and peak concentration $(\mathrm{ng} / \mathrm{ml})$ of FSH \&LH were determined by ELISA (Bovine FSH and LH from USDA Reproduction Lab., Beltsville, MD, USA was used as antigens for preparation of their specific chicken antisera. The procedure was done on three steps, 1) preparation of bovine FSH and LH chicken antisera. 2) Titration of peroxidase labeled goat anti-chicken gamma- globulin, antisera and antigen containing solutions. 3) Estimation of FSH and LH levels by the indirect ELISA (Voller et al., 1979). The sensitivity of the assay was $0.24 \mathrm{ng} /$ tube, the intra and interassay coefficient of variation were $5.3 \%$ and $9.6 \%$ (Less than 10\%) for LH. While, the sensitivity of the assay was $12.0 \mathrm{pg} \mathrm{FSH} \mathrm{/} \mathrm{tube} \mathrm{and} \mathrm{the} \mathrm{intra-} \mathrm{and} \mathrm{inter-}$ assay coefficient of variation were $10 \%$ and $12 \%$, respectively for FSH.

\section{Statistical analysis}

Throughout the experimental study, the obtained data was subjected to statistical analysis, serum progesterone concentrations were analyzed by least square analysis of variance using GLM procedure. All values are expressed as mean $\pm \mathrm{SE}$ relative to the reference standards. The analysis of circulating FSH and LH concentrations were performed using the MIXED procedure (SAS, 2004). Conception rate and interval from calving to first, second and third ovulation were analyzed by least square analysis of variance (SAS, 2004).

\section{RESULTS}

\section{Follicular wave dynamics}

Dominant follicles with diameter $\geq 0.8 \mathrm{~cm}$ were detected 22 days postpartum in GnRH treated group compared to 52 days postpartum in the control group. The dominant follicle that emerged at the first postpartum follicular wave ovulated spontaneously in GnRH treated groups. In the control group, the first wave dominant follicles regressed and the dominant follicle of the third to the fifth postpartum follicular wave ovulated. All animals ovulated before Day 45 postpartum in GnRH treated groups; whereas, none of the cows in control group ovulated within this period of time. The number of follicular waves from calving to the third ovulation had occurred in a short period of time in GnRH treated group compared to control group. Interval from calving to the first, second and third ovulations in GnRH treated group were significantly shorter than in control group (Table 1). 
Table 1: Effect of GnRH administered on day 12-14 postpartum on ovarian dynamics in buffalo-cows

\begin{tabular}{lcc}
\hline \multicolumn{1}{c}{ Treatment } & Control group & $\begin{array}{c}\text { GnRH } \\
\text { treated group }\end{array}$ \\
\hline Number & 10 & 14 \\
\hline No. of FW from parturition till third ovulation & $6.3 \pm 0.7^{\mathrm{a}}$ & $7.4 \pm 0.3^{\mathrm{a}}$ \\
\hline No. of buffaloes ovulated from the first $\mathbf{F W}$ & $0 / 10(0 \%)$ & $10 / 14(71.4 \%)$ \\
\hline No. of buffaloes ovulated before Day 45 postpartum & $0 / 10(0 \%)$ & $14 / 14(100 \%)$ \\
\hline Days from calving to the first ovulation & $65.1 \pm 5.8^{\mathrm{a}}$ & $23.6 \pm 1.4^{\mathrm{b}}$ \\
\hline Days from calving to the second ovulation & $87.6 \pm 6.4^{\mathrm{a}}$ & $45.2 \pm 2.3^{\mathrm{b}}$ \\
\hline Days from calving to the third ovulation & $119.2 \pm 6.3^{\mathrm{a}}$ & $67.8 \pm 1.9^{\mathrm{b}}$ \\
\hline
\end{tabular}

Within the same row, values with different superscript letters $(a, b)$ are significantly different $(\mathrm{P}<0.05)$.

$\mathrm{FW}=$ Follicular Wave.

3.2. Mean diameter of corpus luteum, progesterone concentrations and FSH\& LH profiles

The diameter of CL of the first and second cycles was similar in treated group but the diameter of CL increased from the first cycle to the second cycle in the control group. The mean serum progesterone $\left(\mathrm{P}_{4}\right)$ concentrations were significantly higher in treated group in the first and the second cycle than in the control group. $\mathrm{P}_{4}$ concentration remained at the lowest level $(<0.5 \mathrm{ng} / \mathrm{ml})$ until day 21 postpartum in both treated and control groups, followed by an increase more than $1.0 \mathrm{ng} / \mathrm{ml}$ on day 26 postpartum in treated group. In the control group, the $\mathrm{P}_{4}$ rise above $1.0 \mathrm{ng} / \mathrm{ml}$ was observed later on day 60 postpartum indicating a delay in onset of luteal activity (Table 2). In both treated and control groups, while the peak LH was significantly higher in treated group in comparison with in control group (Table 3). Induced LH release started 0.5 hour after GnRH administration in both treated and control groups. Peak LH release reached within 2 hours after treatment in both treated and control groups (Table 3 ). The injection of a GnRH agonist also induced an increase in serum FSH concentrations at $3 \mathrm{~h}$ compared to the control group (Table 3 ).

Table 2: Effect of GnRH administered on day 12-14 postpartum on the diameter of CL and $\mathrm{P}_{4}$ concentration in buffalo-cows

\begin{tabular}{lccccc}
\hline Treatment & N & \multicolumn{2}{c}{ Diameter of CL $(\mathbf{c m})$} & \multicolumn{2}{c}{$\mathbf{P}_{\mathbf{4}}$ concentration (ng/ml) } \\
\cline { 2 - 5 } & & First cycle & Second cycle & First cycle & Second cycle \\
\hline Control group & 10 & $1.4 \pm 0.4^{\mathrm{a}}$ & $2.1 \pm 0.15^{\mathrm{a}}$ & $1.8 \pm 0.3^{\mathrm{a} *}$ & $3.1 \pm 0.6^{\mathrm{a}} * *$ \\
\hline $\begin{array}{l}\text { GnRH } \\
\text { treated group }\end{array}$ & 14 & $1.9 \pm 0.3^{\mathrm{a}}$ & $2.0 \pm 0.5^{\mathrm{a}}$ & $3.6 \pm 0.2^{\mathrm{b}}$ & $4.1 \pm 0.1^{\mathrm{b}}$ \\
\hline
\end{tabular}

Within the same column, values with different superscript letters $(\mathrm{a}, \mathrm{b})$ are significantly different $(\mathrm{P}<0.05)$. Within the same row, values with different superscript asterisks $(*, * *)$ are significantly different $(\mathrm{P}<0.05) . \mathrm{N}=$ number of animals

Table 3: Effect of GnRH administered on day 12-14 postpartum on FSH\& LH release

\begin{tabular}{lcccc}
\hline \multicolumn{1}{c}{ Parameter } & \multicolumn{2}{c}{ Control group ( $\mathbf{N = 1 0 )}$} & \multicolumn{2}{c}{$\begin{array}{c}\text { GnRH } \\
\text { treated group (n=14) }\end{array}$} \\
\cline { 2 - 5 } & FSH & LH & FSH & LH \\
\hline $\begin{array}{l}\text { 1-Interval from GnRH injection to } \\
\text { start of hormone rise (hours) }\end{array}$ & $0.5 \pm 1.3$ & $0.5 \pm 6.4$ & $0.5 \pm 0.4$ & $0.5 \pm 3.2$ \\
\hline $\begin{array}{l}\text { 2--Interval from GnRH injection } \\
\text { to peak value (hours) }\end{array}$ & $3.0 \pm 2.1$ & $1.8 \pm 3.6$ & $3.5 \pm 2.1$ & $2.0 \pm 5.6$ \\
\hline 3- peak concentration (ng/ $\mathbf{~ m l ) ~}$ & $15.3 \pm 0.8^{*}$ & $12.8 \pm 1.9^{\mathrm{a}}$ & $21.5 \pm 1.7^{* *}$ & $21.4 \pm 3.8^{\mathrm{b}}$ \\
\hline
\end{tabular}

Within the same row, values with different superscript letters $(a, b)$ used for LH release are significantly different $(\mathrm{P}<0.05)$

Within the same row, values with different superscript asterisks $(*, * *)$ used for FSH release are significantly different $(\mathrm{P}<0.05) . \mathrm{N}=$ number of animals 
3.3. Effect of GnRH administered on days 12-14 postpartum on reproductive performance in buffalo-cows The actual intervals from calving to first behavioral estrus and the actual interval from calving to conception (days open) were significantly shorter in the treated group than the control group. In addition the conception rate was higher in treated group than in control group (Table 4).

Table 4: Effect of GnRH administered on day 12-14 postpartum on reproductive performance in buffalo-cows

\begin{tabular}{lcc}
\hline Reproductive criteria & Control group & $\begin{array}{c}\text { GnRH } \\
\text { treated group }\end{array}$ \\
\hline Number & 10 & 14 \\
\hline Postpartum uterine involution(days) & $31.6 \pm 0.2^{\mathrm{a}}$ & $28.3 \pm 0.7^{\mathrm{a}}$ \\
\hline First behavioral estrus (days) & $65.2 \pm 3.4^{\mathrm{a}}$ & $42.6 \pm 1.8^{\mathrm{b}}$ \\
\hline Number of services per conception & $2.4 \pm 0.8^{\mathrm{a}}$ & $1.3 \pm 0.2^{\mathrm{b}}$ \\
\hline Days open & $100.4 \pm 2.6^{\mathrm{a}}$ & $86.9 \pm 1.6^{\mathrm{b}}$ \\
\hline Conception rate & $55.8 \pm 2.6^{\mathrm{a}}$ & $77.4 \pm 1.9^{\mathrm{b}}$ \\
\hline
\end{tabular}

Within the same row, values with different superscript letters $(a, b)$ are significantly different $(P<0.05)$.

\section{DISCUSSION}

The poor reproductive performance in postpartum buffaloes could be partly due to suckling, which is prevalent in developing countries as it inhibits ovarian activity by affecting gonadotropic release in cows (Carruthers and Hafs, 1980). Pituitary sensitivity, as reflected by LH response to synthetic $\mathrm{GnRH}$, is suppressed in the immediate postpartum period and increases gradually by time (DeRensis et al., 1993) till recovery on day 14 after calving (Alam and Dobson, 1987). GnRH administration has been shown to reduce the number of small luteal cells (Helmer and Britt, 1987 and Farin et al., 1988) and increase the number and diameter of large luteal cells and consequently surface area and volume of the CL resulting in positive effect on plasma progesterone levels (Chaikhun et al., 2010 and Ramoun et al., 2012). The gonadotropin response to the exogenous $\mathrm{GnRH}$ analogues treatment observed in pluriparous buffaloes in the present study was similar to that observed in cattle, under such circumstances, plasma LH level was 6 to 8 fold elevated at $30 \mathrm{~min}$ and $3 \mathrm{~h}$ after injection of GnRH (Martinez et al., 2003).

Injection of $20 \mu \mathrm{g}$ of buserelin acetate induced an LH peak between 90 and 165 min in suckled and nonsuckled Murrah buffaloes (Singh et al., 2006). Thus, an exogenous $\mathrm{GnRH}$ analogues injection causes an elevated LH and FSH levels both in cattle (Martinez et al., 2003) and buffaloes (Singh et al., 2006), during shorter duration compared to the preovulatory level. Furthermore, suckling affected the GnRH induced LH release in buffaloes both basal level $(<1.0 \mathrm{ng} / \mathrm{ml})$ or elevated one $(>1.0 \mathrm{ng} / \mathrm{ml})$ (Singh et al., 2006). Plasma progesterone concentration appeared to reflect the suckling induced suppression of GnRH induced LH release. Progesterone appeared to suppress LH through reducing pituitary sensitivity to GnRH and was also found to block the stimulatory effects of estradiol on
GnRH induced LH release by bovine anterior pituitary cell cultures (Padmanabhan and Convey, 1981). In the present study buffaloes that ovulated after treatment with GnRH analogues on days 12- 14 postpartum showed a progressive increase in progesterone concentration in the first and second cycles compared to the control group. Ovulation in buffaloes occurred within $48 \mathrm{hrs}$ of administrating GnRH and progesterone concentration elevated within 96 hrs (Rastegarnia et al., 2004). The interval from calving to complete uterine involution was not affected by administration of GnRH. It has been suggested that uterine involution is more influenced by other variables such as parity, nutrition, calf birth weight, twinning, dystocia, pathology, genetics, season and individual variability (El-Din Zain et al., 1995). However, it can be delayed by persisting subclinical bacterial infection of the postpartum uterus, which can, in turn, delay the occurrence of first postpartum estrus and prolong the service period in buffaloes (Usmani et al., 2001). In the current study, both treated and control groups showed uterine involution within the range reported in literature (28 to 39 days (Perera et al., 1984). Moreover, the interval from calving to the first ovulation occurred earlier in GnRH treated buffaloes than in control group. However, this interval in the control group was relatively similar to those previously reported (McDougall et al., 1995 and Tanaka et al., 2008). Moreover, the number of follicular waves, from parturition to the third ovulation postpartum, was similar in GnRH treated buffaloes and control group. However, the interval from parturition till the third postpartum ovulation was significantly shorter in GnRH treated group than in control group. The obtained data revealed that not only the first postpartum ovulation occurred earlier but also similar number of follicular waves occurred in shorter period of time in $\mathrm{GnRH}$ treated buffaloes compared to control group. Accordingly, it could be concluded that $\mathrm{GnRH}$ hastened the first postpartum ovulation 
leading to multiple cycles in short period of time prior to the first service in buffalo-cows. Moreover, the mean progesterone concentrations were lower in the first cycle compared to the second cycle of the control group. This confirms previous study (Rajamahendran and Taylor, 1990) in which plasma progesterone concentration was significantly lower in the first cycle compared to the second cycle in postpartum cows. The lower progesterone concentration in the control group might be due to the smaller CL diameter established following spontaneous ovulation. In contrast, GnRH treated group, showed no difference in progesterone concentration or CL diameter between the first and second cycle. This could be due to evidence revealed by in vitro experiments suggesting that $\mathrm{GnRH}$ enhances the development and production of progesterone by granulosa cell (Kuran et al., 1996 and Liua et al., 2003) as one of the major cells differentiated to luteal cells (O'Shea et al., 1989 and Lei et al., 1991). In the present study, the incidence of first postpartum behavioural estrous cycle was shorter in Gn-RH treated group than in control one. Short estrous cycle resulting from premature luteolysis is a common documented phenomenon in postpartum cows (Eger et al., 1988). Strategies that stimulated dominant follicle growth before ovulation were associated with increased ovulation rate, enhanced CL development, and greater capacity of $\mathrm{P}_{4}$ production, which are related to maintenance of pregnancy and improved fertility in buffalo (Carvalho et al., 2013).

\section{CONCLUSION}

From the current study we concluded that, GnRH treatment on days 12-14 postpartum enhance the first wave follicle development and early ovulation in buffalo- cows, thus enhance the postpartum behavioral estrus, shorten number of days open, decrease number of services per conception and improve the conception rate.

\section{REFERENCES}

Abdel-Ghani, MA. (2005): Use of a real time ultrasonography for diagnosis of infertility problem in the Egyptian native cattle and buffaloes. M.S. Thesis, Assiut University.

Abol-Roos, MEA. and Gaffar, AEA. (2000): Trials to improve reproductive efficiency of subestrus buffalo cows using PGF2 $\alpha$ at mid luteal phase. Assiut Vet. Med. J. 43, 327-37.

Alam, MGS. and Dobson H. (1987): Pituitary response to a challenge test of $\mathrm{GnRH}$ and estradiol benzoate in postpartum and regularly cyclic dairy cows. J. Anim. Reprod. Sci. 14, $1-9$.
Arya, JS. and Madan, ML. (2001): Postpartum gonadotropins in suckled and weaned buffaloes. Ind. Vet. J. 78, 405-409.

Barile, VL.; Galasso, A.; Marchiori, E.; Pacelli, C.; Montemurro, N. and Borghese, A. (2001): Effect of PRID treatment on conception rate in Mediterranean buffalo-heifers. Livestock Prod. Sci. 68, 283-7.

Barkawi, AK.; Bedeir, LH. and EL-Wardani, MA. (2003): Sexual behavior of Egyptian buffaloes in postpartum period. Buffalo J. 9, 225-36.

Brito, LF.; Satrapa, R.; Marson, EP. and Kastelic, $J P$. (2002): Efficiency of PGF2 $\alpha$ to synchronize estrus in water buffalo cows (Bubalus bubalis) is dependent upon plasma progesterone concentration, corpus luteum size and ovarian follicular status before treatment. J. Anim. Reprod. Sci. 16, 23-35.

Campanile, G.; Vecchio, D.; Neglia, G.; Dipalo, R.; Prandi, A. and D,Occhio, MJ. (2008): Progesterone and pregnancy status of buffaloes treated with a GnRH agonist. Livestock science. 115, 242-248.

Carruthers, TD. and Hafs, HD. (1980): Suckling and four -times daily milking: influence on ovulation, estrus and serum luteinizing hormone, glucocorticoids and prolactin in postpartum Holsteins. J. anim. Sci.50, 919.

Carvalho, NAT.; Soares, JG.; Porto Filho, RM.; Gimenes, LU.; Souza, DC.; Nichi, M.; Sales, JS. and Baruselli, PS. (2013): Equine chorionic gonadotropin improves the efficacy of a timed artificial insemination protocol in buffalo during the nonbreeding season. Theriogenology. 79, 423-428.

Chaikhun, T.; Tharasanit, T.; Rattanatep, J.; De Rensis, F. and Techakumphu, M. (2010): Fertility of swamp buffalo following the synchronization of ovulation by the sequential administration of GnRH and PGF2alpha combined with fixed-timed artificial insemination. Theriogenology. 74, 1371-6.

Das, G. and Khan, F. (2010): Summer Anoestrus in Buffalo - A Review.J. Reprod. Dom. Anim. 45, 483-494.

DeRensis, F.; Hunter, MG. and Foxcroft, GR. (1993): Suckling- induced inhibition of LH secretion and follicular development in the early post-partum sow. J. Biol. Reprod. 48, 964-969.

DeRensis, F.; Ronci, G.; Guarneri, P.; Nguyen, BX.; Presicce, GA. and Huszenicza, G. (2005): Conception rate after fixed time insemination following Ovsynch protocol with and without progesterone supplementation in cyclic and non-cyclic Mediterranean Italian buffaloes (Bubalus bubalis). J. Theriogen. 63, 1824-31.

Eger, M.; Shemesh, H.; Schindler, H.; Amir, S. and Foote, RH. (1988): Characterization of short luteal cycles in the early post-partum period 
and their relation to reproductive performance of dairy cows. J. Anim. Reprod. Sci. 16, 215 224.

El-Din Zain, A.; Nakao, T.; Abdel-Raouf, M.; Moriyoshi, M.; Kawata, K. and Moritsu, Y. (1995): Factors in the resumption of ovarian activity and uterine involution in postpartum dairy cows. J. Anim. Reprod. Sci. 38, 203214.

Farin, CE.; Moeller, CL.; Mayan, H.; Gamboni, F.; Sawyer, HR. and Niswender, GD. (1988): Effect of luteinizing hormone and human chorionic gonadotropin on cell populations in the ovine corpus luteum. J. Biol. Reprod. 38, 413-21.

Helmer, SD. and Britt, JH. (1987): Hormone secretion and characteristics of estrus cycles after treatment of heifers with human chorionic gonadotrophin or prostaglandin F2 $\alpha$ during corpus luteum function. J. Anim. Sci. 64, 782-9.

Kuran, M.; Broadbent, PJ. and Hutchinson, JSM. (1996): Bovine Granulosa cell culture for assessment of potency and specificity of antibodies to pregnant mare serum gonadotrophins. Eur.J. Endocrinol. 134, 497500.

Lei, ZM.; Chegini, N. and Rao, V. (1991): Qualitative cell composition of human and bovine corpora lutea from various reproductive states. J. Biol. Reprod. 44,1148-1156.

Liua, ZH.; Yuea, KZ.; Maa, SF.; Suna, XS. and Tanb, $J H$. (2003): Effects of pregnant mare serum gonadotrophins (eCG) on follicle development and granulose cell apoptosis in the pig. J. Theriogen. 59, 775-785.

Luthra, RA.; Khar, SK. and Singh, KP. (1994): Estrus induction and synchronization in cows and buffaloes with synthetic progesterone. Ind J Anim Sci 64, 1060-1.

Martinez, MF.; Mapletoft, RJ.; Kastelic, JP. and Carruthers, T. (2003): The effect of 3 gonadorelin products on luteinizing hormone release, ovulation, and follicular wave emergence in cattle. Can. Vet. J. 44, 125-131.

McDougall, S.; Burke, CR.; MacMillan, KL. and Williamson, NB. (1995): Patterns of follicular development during periods of anovulation in pasture-fed dairy cows after calving Res. Vet. Sci. 58, 212-216.

McNeilly, AS. and Baird, DT. (1983): Direct effect of prolactin, induced by TRH injection, on ovarian estradiol secretion in ewe. J. Reprod. Fert. 69, 559-568.

McNeilly, AS. and McNeilly, AS. (1988): Suckling and the control of gonadotropin secretion. In: Kobil E, Neill JD, eds. The physiology of mind: being the first part of $3 \mathrm{~d}$ ed., revised, enlarged, and in great part rewritten. (Book title, $3^{\text {rd }} \mathrm{Ed}$.).
Nanda, AS.; Brar, PS. and Prabhakar, S. (2003): Enhancing reproductive performance in dairy buffalo: major constrains and achievements. In: Proceedings of the Sixth International Symposium on Reproduction in Domestic Ruminants, vol. 61, Crieff, Scotland, UK, pp. 27-36.

OShea, JD.; Rodgres, RJ. and D' Occhio, MJ. (1989): Cellular composition of the cyclic corpus luteum of the cow. J. Reprod. Fertil. 85, 483-487.

Padmanabhan, $V$. and Convey, EM. (1981): Progesterone inhibits the ability of estradiol to increase basal and luteinizing hormone releasing hormone induced luteinizing hormone release from bovine pituitary cells in culture. J. Endocrinol. 109, 1091-1095.

Paul, V. and Prakash, BS. (2005): Efficacy of the Ovsynch protocol for synchronization of ovulation and fixed-time artificial insemination in 350 Murrah buffaloes (Bubalus bubalis).J. Theriogen. 64, 1049-60.

Perera BMAO, DeSilvia LNA and Karunaratne, AM. (1984): Studies on reproductive endocrinology and factors influencing fertility in dairy and draught buffaloes in Srilanka, P. 13-28. In proceeding of the use of nuclear techniques to improve domestic buffalo production in Asia. International Atomic Energy Agency, Vienna, Austria.

Presicce, GA.; Senatore, EM.; De Santis, G. and Bella, A. (2005): Follicle turnover and pregnancy rates following oestrus synchronization protocols in Mediterranean Italian buffaloes (Bubalus bubalis). J. Reprod. Dom. Anim. 40, 443-7.

Pursley, JR.; Mee, MO. and Wiltbank, MC. (1995): Synchronization of ovulation in dairy cows using PGF2a and GnRH. J. Theriogen. 44, 915-23.

Rajamahendran, $R$. and Taylor, C. (1990): Characterization of ovarian activity in postpartum dairy cows using ultrasound imaging and progesterone profiles.J. Anim. Reprod. Sci. 22,171-180.

Ramoun, AA.; Serur, BH.; Fattouh, el-SM.; Darweish, SA. and Abou El-Ghait, HA. (2012): Enhancing follicular growth as a prerequisite for $\mathrm{GnRH}$ treatment of true anestrum in buffalo. Anim Reprod Sci. 132, 29-35.

Rastegarnia, A.; Niasari-Naslaaji, A.; Hovareshti, P.; Sarhaddi, F. and Safaei, M. (2004): The Effect of different doses of gonadrolein on ovarian follicle dynamics In river buffalo (Bubalus babalis). J. Theriogen. 62,12831291.

Sastry, NSR.; Thomas, CK. and Singh, RA. (1994): Livestock Production Management. Kalyani Publishers, New Delhi. 
SAS, v 9.1., (2004): $\mathrm{SAS}^{\circledR}$ 9.1.3 Qualification tools User's guide. SAS institute Inc, cary, NC, USA.

Shah, SNH.; Willemse, AH. and VanDeWiel, DFM. (1990): Reproductive performance of NiliRavi buffaloes after a single injection of GnRH early post-partum. J. Trop. Anim. Health Prod. 22 (4), 239-246.

Singh, OO. and Dabas, YPS. (1998): Synchronization of estrus in Murrah buffaloes with prostaglandin to augment milk production in lean period. Ind. J. anim. Reprod. 19, 93-4.

Singh, AK.; Brar, PS.; Nanda, AS. and Prakash, BS. (2006): Effect of suckling on basal and Gn$\mathrm{RH}$ induced $\mathrm{LH}$ release in postpartum dairy buffaloes. Anim. Reprod. Sci. 95,244-250.

Subramaniam, A. and Devarajan, KP. (1991): Oestrous synchronization in nondescript Indian buffaloes with a new intravaginal progesterone pessary and PGF2 $\alpha$. Buffalo J. 7, 101-105.

Tanaka, T.; Arai, M.; Ohtani, S.; Uemura, S.; Kuroiwa, T.; Kim, S. and Kamomae, $H$. (2008): Influence of parity on follicular dynamics and resumption of ovarian cycle in postpartum dairy cows. J. Anim. Reprod. Sci. $108,134-143$.

Usmani RH, Ahmed P, Shafi Q and MirzaMA., 2001. Effect of subclinical uterine infection on cervical and uterine involution, estrous activity and fertility in postpartum buffaloes. J. Theriogen. 55, 563-571.

Voller, A.; Bidwell, DE. and Bartlett, A. (1979): The enzyme Linked Immunosorbent Assay (ELISA). Zool Soc., London.

Wattiaux, MA. (1995): Heat detection and insemination. In: Wattiaux M.A. (Ed.), Technical Dairy Guide: Reproduction and Genetic Selection. The Board of Regents of the University of Wisconsin System,: WI, pp. 19-35.

Xu, Z.; Garverick, HÁ.; Smith, GW.; Smith, MF.; Hamilton, AS. and Youngquist, RS. (1995): Expression of follicle-stimulating hormone and luteinizing hormone receptor messenger ribonucleic acid in bovine follicles during the first follicle wave.J. Biol. Reprod. 53, 951-957.

\section{ديناميكية المبيض، معدلات الإباضة والهرمونات التناسلية الناتجة عن المعالجة المسبقة في مرحلة ما بعد الولادة

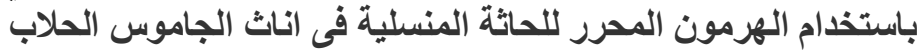

بكار ر مضان عبل الحليم ، نرمبين عاطف حلمى

Email: drbakarwa@yahoo.com

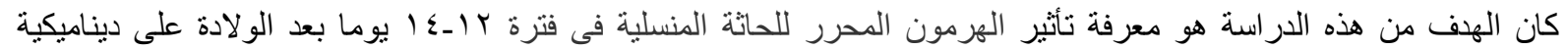

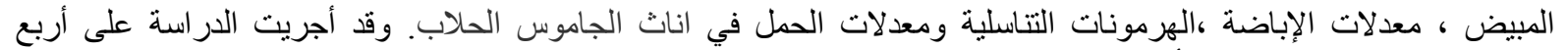

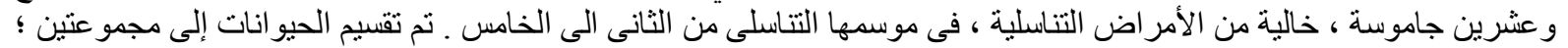

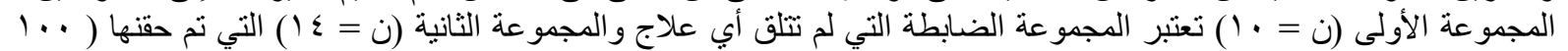

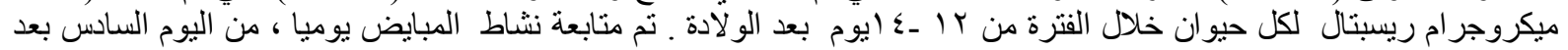

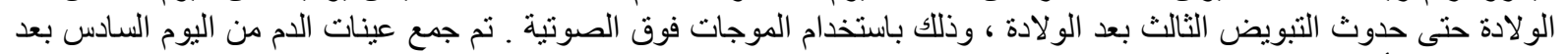

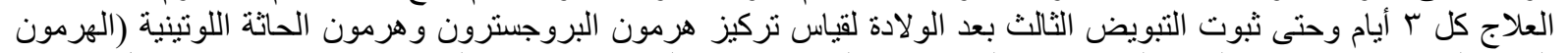

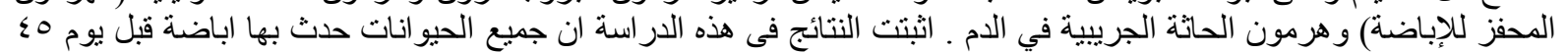

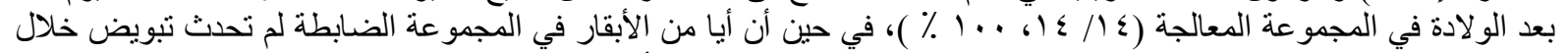

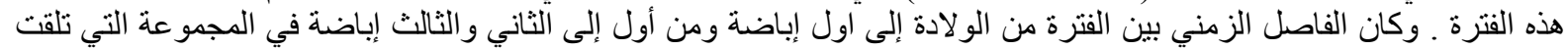

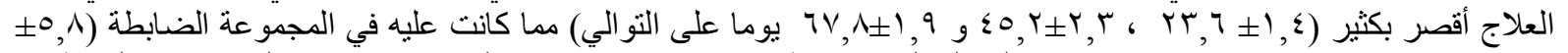

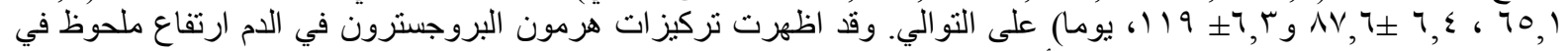

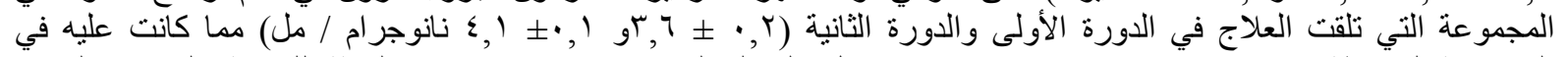

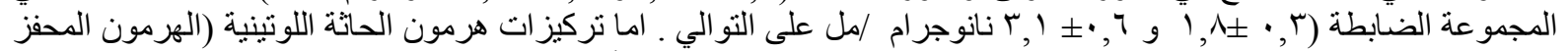

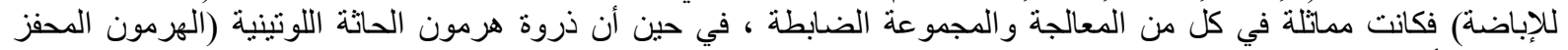

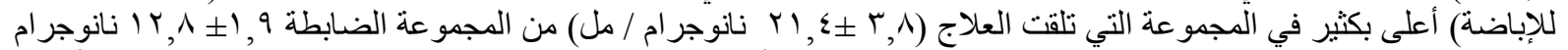

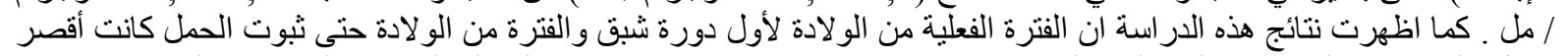

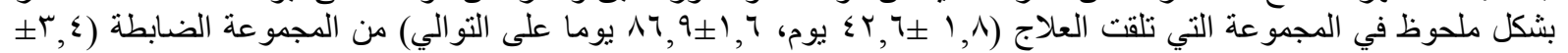

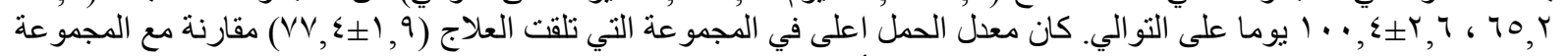

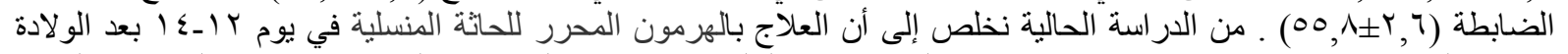

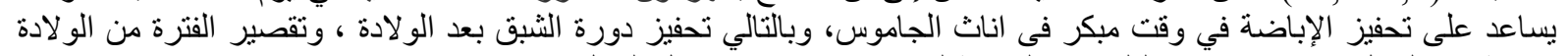
حتى ثبوت الحمل، و انخفاض عدد التلقيحات اللازمة للاخصاب الخاب وتحسين معدل الحمل. 